\title{
Improved serodiagnosis of Lyme disease
}

\author{
M M Davidson, S M Chisholm, A D Wiseman, A W L Joss, D O Ho-Yen
}

\begin{abstract}
Aims-To determine whether enzyme linked immunosorbent assay (ELISA) results for Borrelia burgdorferi require confirmation by immunoblotting and how immunoblotting may best be used in the diagnosis of Lyme disease.

Methods-Over one year, all referrals for Lyme disease to a district general hospital with a large tick population in its catchment area were tested by ELISA. Positive, low positive and negative serum samples were subjected to immunoblotting and the reactive bands analysed.
\end{abstract}

Results-In total, 633 samples were received; 38 were ELISA positive and 97 low positive. More serum samples were from rural $(n=356)$ than from urban $(n=277)$ areas but a higher percentage of serum samples from urban areas were ELISA positive. The ELISA results were confirmed by immunoblotting in $15 / 38$ positive samples but in only four of 37 with a low positive titre. An IgM positive blot required a $41 \mathrm{kDa}$ band plus $\geq 1$ specific band; for IgG a $41 \mathrm{kDa}$ band plus $\geq 2$ specific bands were necessary. Five serum samples were IgM positive with a $41 \mathrm{kDa}$ plus one or more other specific bands. For IgG blots, the best discrimination was seen with the $21,31,46$, and $92 \mathrm{kDa}$ bands. Nonspecific, weakly reacting bands at 55,60 and $67 \mathrm{kDa}$ were frequently seen. Infection was confirmed in four of six patients with arthritis, but in only one of 10 patients with erythema chronicum migrans.

Conclusions-ELISA alone is insufficient for diagnosis. All positive and low positive or negative serum samples with a good clinical history should be examined by immunoblotting. A higher percentage of modified ELISA positive than low positive results were confirmed. There are significant differences between European and American immunoblotting patterns. Local results show similarity to American results, highlighting the need for a local Borrelia isolate.

(f Clin Pathol: Mol Pathol 1996;49:M80-M84)

Keywords: Lyme disease, ELISA, immunoblotting, Borrelia burgdorferi.

Two decades after the identification of Lyme disease, it is disappointing that the role of laboratory diagnosis is minor and many feel that diagnosis should be based on clinical and epidemiological evidence of infection. ${ }^{1}$ Laboratory diagnosis has depended on serological tests, immunofluorescence or enzyme linked immunosorbent assay (ELISA), which are widely regarded as lacking sensitivity, specificity and interlaboratory reproducibility. ${ }^{2-4}$ How can laboratory diagnosis be improved? It has been suggested recently that ELISAs should be used as screening tests with confirmation of positive results by immunoblotting. ${ }^{5}$ However, there is no standard protocol defining which immunoblot banding pattern is diagnostic ${ }^{2}$ and different criteria have been suggested by various groups..$^{5-9}$ Laboratory tests should also take into account the characteristics of the causative spirochaete Borrelia burgdorferi, ${ }^{15}$ such as delayed antibody response $^{3}$ or lack of antibody production where there is prompt appropriate antibiotic treatment. $^{2}$

Lyme disease is endemic in the Scottish Highlands, an area in which there is a very large population of ticks (Ixodes ricinus) and many patients who recall a history of tick bites. ${ }^{10}$ Laboratory analysis is often required in the diagnosis of Lyme disease, and there is a need to give more specific advice. Whereas classic erythema chronicum migrans (ECM) seen early in infection may be easy to diagnose clinically, the vague and less specific symptoms (arthritic, cardiac, neurological, etc) seen in late Lyme disease ${ }^{11}$ require additional investigation. Our laboratory has to be pragmatic and adopt a protocol for diagnosis which has scientific validity and satisfies the demands of users.

\section{Methods}

From September 1994 to August 1995, all serum samples from patients with symptoms regarded as consistent with Lyme disease were tested for antibodies directed against $B$ burgdorferi at Raigmore Hospital NHS Trust, Inverness. The serum samples were received from general practitioners and hospital consultants.

\section{CULTURE OF B BURGDORFERI}

$B$ burgdorferi (ACA-1) was cultured in BSK-H medium (Sigma, Poole, Dorset, UK) for seven days at $34^{\circ} \mathrm{C}$. Cells from $50 \mathrm{ml}$ medium were harvested by centrifugation at $3000 \times g$ for 30 minutes and washed twice in phosphate 
buffered saline (PBS). After the final wash the cells were resuspended in $1.5 \mathrm{ml}$ distilled water and stored at $-70^{\circ} \mathrm{C}$ until used as antigen for immunoblotting.

ELISA

All serum samples were tested routinely by ELISA for total antibody directed against $B$ burgdorferi (Human Lyme EIA, Cambridge Biotech) following the manufacturer's instructions but with differences in interpretation. Serum samples were only reported as positive if the absorbance values were greater than twice the cut off level recommended by the manufacturer. Serum samples falling between the cut off and twice the cut off level were regarded as low positive. All positive serum samples were tested further for rheumatoid factor (Microgen, Camberley, UK) and antibody directed against Treponema pallidum (TPHA; Mast Laboratories, Liverpool, UK).

\section{IMMUNOBLOTTING}

$B$ burgdorferi antigens in distilled water were mixed with an equal volume of lysis buffer containing $4 \%$ sodium dodecyl sulphate and $2 \%$ mercaptoethanol, aliquoted, stored at $-20^{\circ} \mathrm{C}$, and boiled for five minutes before use. Proteins were separated on a $10 \%$ polyacrylamide gel with a $3 \%$ stacking gel as described by Laemmli. ${ }^{12}$ Gels were electrophoresed overnight at $8 \mathrm{ma} / g e l$. Proteins were transferred to nitrocellulose in an LKB Transfor immunoblotter at $0.4 \mathrm{amp}$ for four hours. Membranes were blocked in 5\% dried skimmed milk (Safeway) in PBS for one hour, rinsed in PBS with Tween 20 (PBST), dried, and stored in the dark at room temperature for up to one month. All subsequent steps were done on a rocking table at room temperature. Strips were reacted with human serum samples, 1:50 in $5 \%$ milk/PBST overnight, washed six times in PBST followed by either anti-human IgG (1:4000) or IgM (1:2000) conjugated with horseradish peroxidase (Sigma) diluted in 5\% milk/PBST for two hours. After five washes in PBST and one in PBS, substrate containing 5chloronaphthol (Sigma) and hydrogen peroxide was added for 10 minutes, washed in PBST for 30 minutes, rinsed in distilled water, and dried. A mixture of known molecular weight markers (SDS7, Sigma) was run on each gel, stained with Amido Black and used as standards to determine the molecular weights of test proteins. Monoclonal antibodies directed against $B$ burgdorferi antigens (Chemical International Inc., Quadratech, Surrey, UK) were tested by immunoblotting at several dilutions using anti-mouse horseradish peroxidase conjugates (SAPU, Carluke, Scotland).

\section{STATISTICS}

Where appropriate, data were subjected to statistical analysis by $\chi^{2}$ test or Fisher's exact test.
Table 1 ELISA results: geographical distribution

\begin{tabular}{llc}
\hline \multirow{2}{*}{ ELISA Results } & \multicolumn{2}{l}{ No. (\%) in each category } \\
\cline { 2 - 3 } & \multicolumn{1}{l}{ Urban } & \multicolumn{1}{c}{ Rural } \\
\hline Positive & $26(9 \cdot 3)$ & $12(3 \cdot 3)^{* *}$ \\
Low positive & $46(16 \cdot 5)$ & $51(14 \cdot 3)$ \\
Negative & $205(74 \cdot 2)$ & $293(82 \cdot 4)$ \\
Total & $277(100)$ & $356(100)$ \\
\hline
\end{tabular}

${ }^{* *} \mathrm{p}<0.01$.

Table 2 Interpretation of immunoblot banding patterns

\begin{tabular}{|c|c|c|c|c|}
\hline \multirow[b]{2}{*}{ Interpretation } & \multicolumn{4}{|c|}{ Bands detected } \\
\hline & Total & Specific* & Intensity† & $41 \mathrm{kDa}$ \\
\hline \multicolumn{5}{|l|}{ IgM $\ddagger$} \\
\hline $\begin{array}{l}\text { Positive } \\
\text { Negative } \\
\text { IgG }\end{array}$ & $\begin{array}{l}\geq 2 \\
\leq 3\end{array}$ & $\begin{array}{r}\geq 1 \\
0\end{array}$ & $\begin{array}{l}2 \text { to } 4 \\
1\end{array}$ & $\begin{array}{l}+ \\
+1-\end{array}$ \\
\hline $\begin{array}{l}\text { Positive } \\
\text { Equivocal }\end{array}$ & $\begin{array}{l}\geq 4 \\
4-6\end{array}$ & $\begin{array}{r}\geq 2 \\
1\end{array}$ & $\begin{array}{l}2 \text { to } 4 \\
2 \text { to } 4\end{array}$ & $\begin{array}{l}+ \\
+\end{array}$ \\
\hline Negative & $\leq 6$ & 0 & 104 & $+1-$ \\
\hline
\end{tabular}

* Specific bands: 19, 21, 26, 29, 31, 34, 39, 42, 46, and $92 \mathrm{kDa}$. $\dagger 1=$ weak; $2=$ moderate; $3=$ strong; $4=$ very strong. $\ddagger$ Immunoblot.

\section{Results}

ELISA

In total, 633 serum samples were received from 560 patients during the study period. Positive results were found in $38(6 \%)$ serum samples from $26(4 \cdot 6 \%)$ patients. All were TPHA negative and five serum samples from three patients were positive for rheumatoid factor. Ninety seven serum samples $(15 \cdot 3 \%)$ from 84 patients $(15 \%)$ were low positive. More serum samples were received from rural $(n=356)$ than from urban $(n=277)$ areas (table 1$)$, but a significantly higher percentage of positive serum samples were seen in the urban community $\left(\chi^{2}\right.$ $\mathrm{p}<0.01)$.

\section{IMMUNOBLOTTING}

All 38 positive, 37 low positive and 30 negative serum samples were tested by immunoblotting. Only five serum samples were IgM positive, four of which were ELISA positive and one ELISA negative. Bands at 55, 60 and $67 \mathrm{kDa}$ were seen both in positive and negative serum samples, but usually reacted weakly. Four of the five positive samples had a $41 \mathrm{kDa}$ band plus one other at either 21,31 or $92 \mathrm{kDa}$. The fifth had three bands at 29, 31 and $41 \mathrm{kDa}$. IgG results were interpreted according to criteria which take account of the presence of specific and non-specific bands (table 2). Positive results were confirmed in 15 of the 38 positive serum samples (eight patients), but only four serum samples with low positive titres $\left(\chi^{2}\right.$ $\mathrm{p}<0.01$ ) gave a positive result on immunoblotting. Two ELISA positive patients with early stage symptoms had equivocal immunoblots and further samples were requested but not received. Two ELISA negative serum samples gave a positive immunoblot but follow up serum samples were not available. The frequency of detection of each IgG reactive $B$ burgdorferi protein band is shown in table 3 . The most frequently detected band was the $41 \mathrm{kDa}$ flagellin protein. This was present in all positive serum samples but also in $62 \%$ of 
Table 3 Frequency of detection of IgG immunoblot bands

\begin{tabular}{|c|c|c|c|c|c|c|c|c|c|c|c|c|c|c|c|c|}
\hline \multirow[b]{2}{*}{$E L I S A$} & \multirow[b]{2}{*}{ Immunoblot } & \multicolumn{15}{|c|}{ Number of times bands detected } \\
\hline & & 19 & 21 & 26 & 29 & 31 & 34 & 39 & 41 & 42 & 46 & 55 & 60 & 67 & 72 & $92 k D a$ \\
\hline Positive & $\begin{array}{l}\text { Positive }(n=15) \\
\text { Equivocal }(n=2) \\
\text { Negative }(n=21)\end{array}$ & $\begin{array}{l}5 \\
0 \\
0\end{array}$ & $\begin{array}{l}7 \\
0 \\
0\end{array}$ & $\begin{array}{l}3 \\
0 \\
0\end{array}$ & $\begin{array}{l}4 \\
1 \\
0\end{array}$ & $\begin{array}{l}8 \\
0 \\
0\end{array}$ & $\begin{array}{l}3 \\
0 \\
0\end{array}$ & $\begin{array}{l}2 \\
2 \\
0\end{array}$ & $\begin{array}{r}15 \\
1 \\
19\end{array}$ & $\begin{array}{l}3 \\
0 \\
0\end{array}$ & $\begin{array}{l}6 \\
0 \\
0\end{array}$ & $\begin{array}{r}11 \\
0 \\
13\end{array}$ & $\begin{array}{r}10 \\
0 \\
6\end{array}$ & $\begin{array}{l}5 \\
0 \\
8\end{array}$ & $\begin{array}{l}7 \\
1 \\
3\end{array}$ & $\begin{array}{l}8 \\
0 \\
0\end{array}$ \\
\hline Low Positive & $\begin{array}{l}\text { Positive }(n=4) \\
\text { Equivocal }(n=3) \\
\text { Negative }(n=30)\end{array}$ & $\begin{array}{l}0 \\
0 \\
0\end{array}$ & $\begin{array}{l}0 \\
0 \\
0\end{array}$ & $\begin{array}{l}0 \\
0 \\
0\end{array}$ & $\begin{array}{l}1 \\
0 \\
0\end{array}$ & $\begin{array}{l}3 \\
1 \\
0\end{array}$ & $\begin{array}{l}1 \\
0 \\
0\end{array}$ & $\begin{array}{l}0 \\
0 \\
0\end{array}$ & $\begin{array}{r}4 \\
3 \\
19\end{array}$ & $\begin{array}{l}0 \\
0 \\
0\end{array}$ & $\begin{array}{l}2 \\
0 \\
0\end{array}$ & $\begin{array}{l}1 \\
1 \\
5\end{array}$ & $\begin{array}{l}2 \\
0 \\
9\end{array}$ & $\begin{array}{l}0 \\
0 \\
3\end{array}$ & $\begin{array}{l}1 \\
1 \\
0\end{array}$ & $\begin{array}{l}1 \\
1 \\
1\end{array}$ \\
\hline Negative & $\begin{array}{l}\text { Positive }(n=2) \\
\text { Equivocal }(n=3) \\
\text { Negative }(n=25)\end{array}$ & $\begin{array}{l}0 \\
0 \\
0\end{array}$ & $\begin{array}{l}0 \\
0 \\
0\end{array}$ & $\begin{array}{l}0 \\
0 \\
0\end{array}$ & $\begin{array}{l}0 \\
0 \\
0\end{array}$ & $\begin{array}{l}1 \\
1 \\
0\end{array}$ & $\begin{array}{l}1 \\
0 \\
0\end{array}$ & $\begin{array}{l}0 \\
0 \\
0\end{array}$ & $\begin{array}{l}2 \\
3 \\
9\end{array}$ & $\begin{array}{l}0 \\
0 \\
0\end{array}$ & $\begin{array}{l}1 \\
0 \\
0\end{array}$ & $\begin{array}{r}2 \\
1 \\
10\end{array}$ & $\begin{array}{l}1 \\
1 \\
8\end{array}$ & $\begin{array}{l}0 \\
1 \\
0\end{array}$ & $\begin{array}{l}1 \\
0 \\
0\end{array}$ & $\begin{array}{l}1 \\
1 \\
0\end{array}$ \\
\hline
\end{tabular}

negative serum samples. The best discrimination was seen with the lower molecular weight bands $(19-39 \mathrm{kDa})$ especially the 21 and $31 \mathrm{kDa}$ bands. The 42 and $46 \mathrm{kDa}$ bands were not found in negative serum samples, but were present in $<50 \%$ of positive serum samples. The $92 \mathrm{kDa}$ band was present in $50 \%$

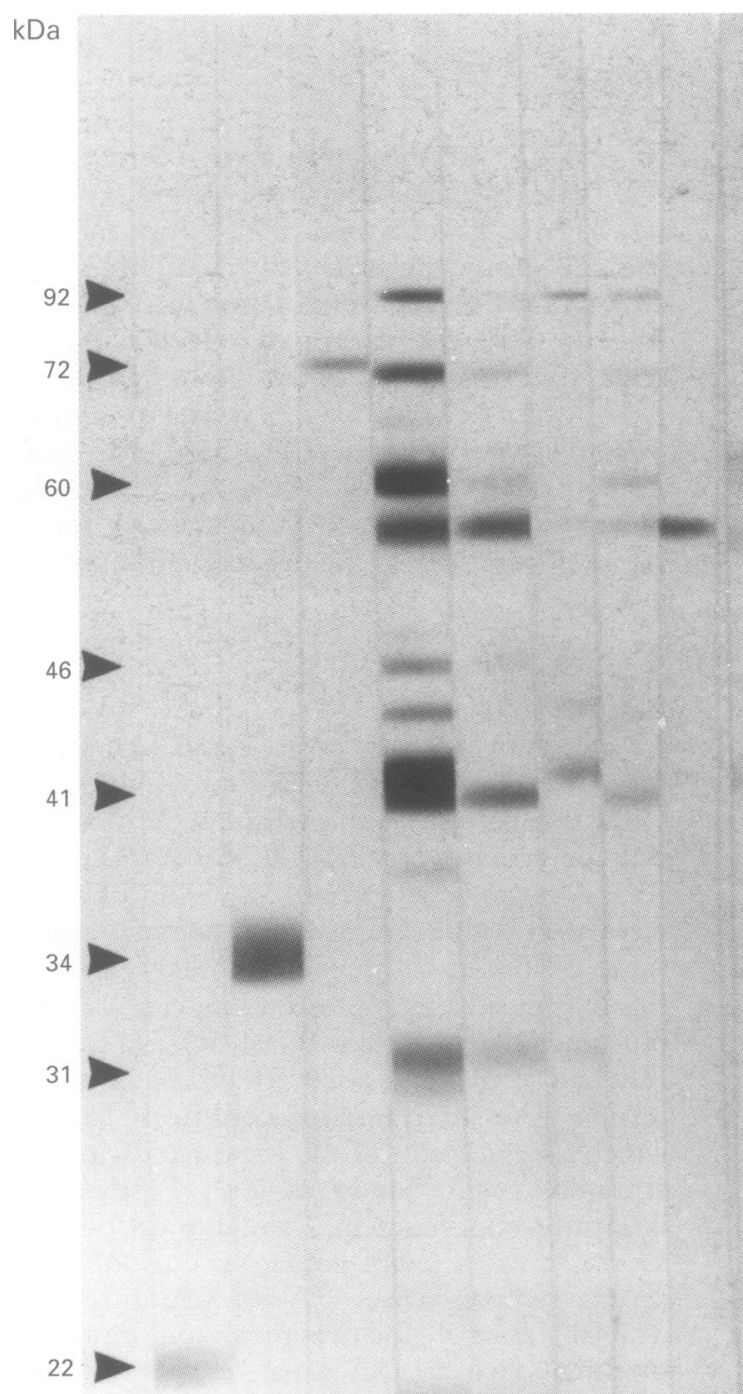

Figure 1 Lyme immunoblots. Lane A, monoclonal antibody (MAb) 962 (22 kDa); lane $B, M A b 954(34 k D a)$; lane $C, M A b 958(72 \mathrm{kDa})$; lanes $D-E$, positive IgG blots; lanes $F$ and $G$, equivocal IgG blots; lane $H$, positive IgM blot; lanes $I-L$, negative blots. of positive serum samples and only once found in a negative specimen. As with $\operatorname{IgM}$, weakly reacting IgG bands at 55, 60 and $67 \mathrm{kDa}$ were seen both in positive and negative serum samples. Representative immunoblots are shown in fig 1 .

There was considerable variation in the number of bands (from four to 12) detected in IgG positive serum samples. Examination of sequential serum samples from five patients showed that IgM may disappear within four weeks of onset of symptoms. It was also apparent that late samples taken several months after onset may yield equivocal results unless results of acute serum samples are available for comparison.

In four of six patients with arthritis, ELISA positive results were confirmed by immunoblotting. In contrast, in patients with possible early stage disease manifesting as ECM only one of 10 ELISA positive results was confirmed (Fisher's exact test, $\mathrm{p}<0 \cdot 03$ ); two were equivocal and further samples were requested.

\section{Discussion}

In the Scottish Highlands there is a narrow distinction between urban and rural communities. There are no cities anywhere in the region and the largest town, Inverness, has easy access to neighbouring countryside, in which there are sheep, deer and ticks. Roe deer, a common host, regularly frequent suburban gardens. The tick, sheep and deer populations are unquestionably higher in rural areas and it is not surprising that most of the samples in this study were from rural areas. However, it is surprising that a significantly higher percentage of positive serum samples came from urban areas $\left(\chi^{2} p<0 \cdot 01\right)$. The results suggest infected ticks may be more prevalent in the countryside around urban areas, with the possibility that ticks shed by wild animals visiting gardens are more likely to encounter humans than other animals to act as secondary host. Six years after our original investigation, ${ }^{10}$ when pockets of infection were identified, especially in forested areas, the number of patients tested annually has increased from 183 to 560 , a rise of $306 \%$. This perhaps represents a greater awareness of Lyme disease. The percentage positive results had fallen from $27 \%(50 / 183)$ to $19 \cdot 6(110 /$ $560)$ but this was not significant $\left(\chi^{2} p>0 \cdot 05\right)$. If these results are representative of other areas in the country, the increased awareness of Lyme 
Table 4 Major bands found in IgG immunoblots

\begin{tabular}{|c|c|c|c|c|c|c|c|c|c|c|c|c|c|c|c|c|c|}
\hline \multirow[b]{2}{*}{ Reference } & \multirow[b]{2}{*}{ Country } & \multicolumn{16}{|c|}{ Band $(k D a)$} \\
\hline & & $<19$ & $20-22$ & $23-26$ & $27-29$ & 30 and 31 & 34 and 35 & $37-39$ & 41 & $42-46$ & $48-50$ & $55-58$ & 60 & 66 and 67 & $70-75$ & $83-88$ & $>92$ \\
\hline Seppala et $a l^{13}$ & Finland & ++ & ++ & - & - & ++ & ++ & ++ & ++ & - & ++ & - & + & + & + & ++ & - \\
\hline Lange $e t a l^{14}$ & Germany & - & ++ & ++ & ++ & ++ & ++ & $+t$ & ++ & - & - & - & + & - & + & - & ++ \\
\hline Zoller et al ${ }^{15}$ & Germany & ++ & ++ & ++ & - & ++ & ++ & ++ & ++ & ++ & - & - & ++ & - & ++ & - & ++ \\
\hline Karlsson ${ }^{16}$ & Sweden & ++ & ++ & ++ & - & - & - & $+t$ & ++ & - & - & - & - & - & - & - & - \\
\hline Rees $e t a l^{17}$ & UK & $+t$ & ++ & - & - & ++ & - & - & $+t$ & - & $+t$ & - & $+t$ & - & $+t$ & ++ & - \\
\hline Cutler et $a l^{5}$ & UK & + & ++ & - & - & ++ & ++ & ++ & ++ & - & ++ & ++ & + & + & + & ++ & ++ \\
\hline Our results & UK & + & ++ & + & + & ++ & + & + & ++ & ++ & - & ++ & ++ & - & ++ & - & ++ \\
\hline Fister $e t a l^{18}$ & USA & ++ & - & ++ & - & ++ & $+t$ & - & ++ & - & - & ++ & - & ++ & - & - & - \\
\hline Sood et al ${ }^{19}$ & USA & - & $+t$ & - & + & ++ & - & - & ++ & $+t$ & - & ++ & - & - & - & - & - \\
\hline $\begin{array}{l}\text { Dressler et } a l^{8} \\
\text { Kowal and }\end{array}$ & USA & ++ & ++ & - & ++ & ++ & ++ & ++ & ++ & ++ & - & ++ & - & ++ & ++ & - & ++ \\
\hline Weinstein ${ }^{20}$ & USA & ++ & ++ & ++ & ++ & ++ & ++ & ++ & ++ & ++ & - & - & ++ & ++ & ++ & ++ & - \\
\hline Engstrom et $a l^{9}$ & USA & - & ++ & $+t$ & - & + & ++ & ++ & ++ & - & - & ++ & - & - & ++ & ++ & - \\
\hline
\end{tabular}

$-=$ Not reported; $+=$ present; $++=$ common.

disease has resulted in a significant increase in workload in laboratories.

Because of cross-reactions, especially with other spirochaetes, ELISA tests lack specificity. ${ }^{15}$ One report has suggested that only $16.3 \%$ of ELISA positive samples could be confirmed by immunoblotting. ${ }^{5}$ The majority $(97 / 135,74 \%)$ of ELISA positive results in this study were in the low positive category. Applying criteria normally used for any other serological test, low positive results in a single specimen were not regarded as diagnostic, although further testing was recommended for patients with symptoms of recent onset. By modifying the manufacturer's criteria for a positive reaction, we were able to confirm ELISA positive results in $31 \%$ of patients. In contrast, the observation that results of only $11 \%$ of patients in the low positive group were confirmed by immunoblotting $\left(\chi^{2} \mathrm{p}<0.01\right)$ provides some justification for the modification, especially as the low positive serum samples chosen for immunoblotting had a bias towards those patients with the most likely clinical symptoms. The finding that two patients with ELISA negative results were positive by immunoblotting confirms previous false negative reports for ELISA tests. ${ }^{15}$ If ELISA tests are used for screening, patients with classic histories for Lyme disease or early in the illness may also need to be tested by immunoblotting even if ELISA negative.

Important considerations in the assessment of immunoblotting are the criteria used to define a positive result. Band intensity is too variable to be consistently considered ${ }^{5}$ and the presence of critical bands also vary from study to study. ${ }^{7-913-20}$ Obviously, precise comparisons cannot be made as there are differences in methodology. However, there seems to be significant differences between North American and European results (table 4 ) which suggests that a major factor is strain diversity, especially in European serum samples. In the USA several bands are frequently reported that are uncommon in Europe: 27-29, 42-46, and 66 and $67 \mathrm{kDa},{ }^{8918-20}$ whereas bands at $48-50$ and $60 \mathrm{kDa}$ are more common in Europe. ${ }^{5}$ Our results are consistent with this. The $41 \mathrm{kDa}$ band was present in all our positive immunoblots and also in most negative immunoblots. This is consistent with the hypothesis that this band is a non-specific or genus specific marker, ${ }^{6}$ but it should be present in all positive results. ${ }^{5}$ The $20-22$ and 30 and $31 \mathrm{kDa}$ bands were more specific. We also identified 55, $70-75$ and $92 \mathrm{kDa}$ bands which are not commonly noted by others. Apart from the $92 \mathrm{kDa}$ band, these are considered to be non-specific, ${ }^{6}$ which our data would seem to support. An interesting finding was the frequency of detection of the $55 \mathrm{kDa}$ band, second only to the $41 \mathrm{kDa}$ band in the positive immunoblots. This band is mentioned by only one other European author, ${ }^{73-17}$ and its common presence in negative immunoblots may be consistent with a local, Highland cross-reacting protein. Also, the fact that in some serum samples we detected bands at 29, 42 and $46 \mathrm{kDa}$, all of which are rarely reported in Europe, but which are common in the USA, is suggestive of strain variation between the Scottish Highlands and the rest of Europe.

In patients with sequential samples available the IgG band pattern was quite stable over time, although, as might be expected, IgM bands were less frequent in follow up samples. It is interesting that the $55 \mathrm{kDa}$ band is present in four of six patients with arthritis and these patients had frequent exposure to tick bites. When the clinical presentation was considered, immunoblots were most useful in making the diagnosis in patients with arthritis and least useful in patients with ECM.

The media focus on Lyme disease and the large local population of ticks in our area has resulted in a significant increase in sample referrals to this district general hospital. Lyme disease has all of the complexity of a spirochaetal infection. To provide the best diagnostic service, it is important to utilise the full capabilities of the laboratory. Our results demonstrate that ELISA tests alone are insufficient for diagnosing Lyme disease. Despite the cost, it is now imperative that all positive ELISA results are confirmed by immunoblotting. Furthermore, patients with negative or low positive ELISA results but good clinical evidence of Lyme disease, especially those with arthritis, should also be tested by immunoblotting. As immunoblots have to be interpreted according to the banding patterns prevalent in the area of testing, isolation of a local strain of the organism and adapting serological tests (that is, ELISA and immunoblotting) to its antigenic composition 
would improve serodiagnosis further. The recent use of the polymerase chain reaction to detect $B$ burgdorferi DNA in serum samples ${ }^{4}$ is also a welcome initiative which requires confirmation. When all these approaches have been fully developed it is likely that laboratory diagnosis will be the equal of this spirochaete.

We are grateful to Dr G Stone for a Highland Health Board grant; the Moray Firth ME Association for financial support; hospital consultants and general practitioners for providing us with samples; Mrs K Crawford, Medical Illustration, for photographic work; Dr S O'Connell, Southampton PHL providing us with the ACAl strain of B burgdorferi; and to Lorna Wycherley for secretarial assistance.

1 Magnarelli LA. Current status of laboratory diagnosis for Lvme disease. Am 7 Med 1995;98:10S-12S.

2 Golightly MG, Thomas JA. Lvme borreliosis serologies in perspective. Clinical Immunologv' Newsletter 1991;11: $113-18$.

3 Rahn DW, Malawista SE Lyme disease: recommendation for diagnosis and treatment. Anm Intern Med 1991;114 $472-81$.

4 Oksi J, Uksila J, Marjamaka M, Nikoskelainen J, Viljanen MK. Antibodies against whole sonicated Borrelia burgdorferi spirochaetes, 41-kilodalton flagellin, and P39 protein in patients with PCR or culture proven late Lyme borreliosis. F Clin Microbiol 1995;33:2260-4

5 Cutler SJ, Wright DJM. Predictive value of serology in diagnosing Lyme borreliosis. F Clin Pathol 1994;47:344-9.

6 Tilton RC, Ryan RW. The laboratory diagnosis of Lyme disease. 7 Clin Immumoassay 1993;16:208-14.

7 Cutler SJ, Wright DJM, Luckhurst VH. Simplified method for the interpretation of immunoblots for Lyme borreliosis. FEMS Immunol Med Microbiol 1993;6:281-6.
8 Dressler F, Whalen JA, Reinhardt BN, Steere AC. Western blotting in the serodiagnosis of Lyme disease. F Infect Dis

9 Engstrom SM, Shoop E, Johnson RC. Immunoblot interpretation criteria for serodiagnosis of early Lyme disease. 7 Clin Microbiol 1995;33:419-27.

10 Ho-Yen D, Bennet AJ, Chisholm S, Deacon AG. Lyme disease in the Highlands. Scot Med $\mathcal{F}$ 1990;35:168-70.

11 Pfister HW, Wilske B, Weber K. Lyme borreliosis: basic science and clinical aspects. Lancet 1994;343:1013-16.

$12 \mathrm{~L}$ aemmli UK. Cleavage of structural proteins during the assembly of the head of bacteriophage T4. Nature 1970; 227:680-5

13 Seppala IJT, Kroneld R, Schauman K, Forsen KO, Lassenius R. Diagnosis of Lyme borreliosis: non-specific serological reactions with Borrelia burgdorferi sonicate antigen logical reactions with Borrelia burgdorferi sonicate antigen 293-302.

14 Lange R, Bocklage H, Schneider T, Kolmel HW, Heesemann J, Karch H. Ovalbumin blocking improves sensitivity and specificity of immunoglobulin $\mathrm{M}$ immunoblotting for serodiagnosis of patients with erythema migrans. F Clin Microbiol 1992;30:229-32.

15 Zoller L, Burkard S, Schafer H. Validity of Western immunoblot band patterns in the serodiagnosis of Lyme borreliosis. F Clin Microbiol 1991;29:174-82.

16 Karlsson $M$. Western immunoblot and flagellum enzymelinked immunosorbent assay for serodiagnosis of Lyme linked immunosorbent assay for serodiagnosi
borreliosis. 7 Clin Microbiol 1990;28:2148-50.

17 Rees DHE, O'Connell S, Brown MM, Robertson J, Axford JS. The value of serological testing for Lyme disease in the UK. Br F Rheumatol 1995;34:132-6.

8 Fister RD, Weymouth LA, McLaughlin JC, Ryan RW, Tilton RC. Comparative evaluation of three products for the detection of Borrelia burgdorferi antibody in human serum. F Clin Microbiol 1989;27:2834-7.

19 Sood SK, Rubin LG, Blader ME, Ilowite NT Positive serology for Lyme borreliosis in patients with juvenile rheumatoid arthritis in a Lyme borreliosis endemic area: analysis by immunblot. F Rheumatol 1993;20:739-41.

20 Kowal K, Weinstein A. Western blot band intensity analysis. Arthritis Rheum 1994;37:1206-11. 